\title{
RELATIONSHIP BETWEEN THE STUDENTS' FUNCTIONAL STATUS OF ORGANISM, BODY COMPOSITION AND HEALTH SELF-ASSESSMENT
}

\author{
Helēna Vecenāne \\ Liepaja University \\ Andra Fernāte \\ Latvian Academy of Sport Education
}

\begin{abstract}
The person's physical and mental health is a topical issue nowadays, as often it is believed that all the responsibility for person's health must be in the hands of the state health care institutions. Educating society on health issues in various levels is very perspective, especially important it is at the educational establishments. If the education on health related issues is continuously taking place in comprehensive educational establishments, insufficient attention is paid to it in the higher educational establishments. The aim of the research is to define the correlations between the functional state of the organism, body composition and health assessment of students of Liepaja University and Riga Stradins University Liepaja Branch. The research results proved that the correlation between the students 'functional condition of organism, body composition and health self- assessment can be evaluated as weak. A significant correlation between the students' functional condition of organism and body composition was not found.
\end{abstract}

Key words: students, functional condition of human body, body composition, health selfassessment

\section{Introduction}

The functional condition of the organism, body composition and health assessment are important indicators for evaluating the person's general health condition. It happens that after assessing these indicators people decide to change their behavioural habits in order to improve their health. The research studies suggest that the wholesome information, physical environment and social support are of great importance (Kaupužs A., Lāriņš V.,2010; Adams, T., Moore, М.,2007; Чуян, Е.Н., Бирюкова, Е.А., \& Раваева, М.Ю., 2008; Батоцыренова Т.Е., Иванов С.В.,2011 and many others) Unfortunately, in Latvia after regaining its independence, the higher educational establishments do not offer anymore mandatory sports classes, where students could not only improve their athletic abilities, obtain the necessary information, but also they were entitled to annual medical tests without any fees. At the moment the necessity to engage in sports activities also in higher educational establishments has been emphasized, providing the theoretical information about healthpromoting activities besides the practical activities. Despite the abundance of information, it is important to ensure that health promoting activities are accessible to students also in higher educational institutions. The aim of this research is to define the correlations of the functional state of the organism, 
body composition and health assessment of full and part time students of Liepaja University and Riga Stradins University Branch of Liepaja. For defining the functional condition of the organism we employed the hardware-software complex "Dinamika Medicine". The results are obtained on the basis of mathematical-statistical analysis of heart rate variability and measurements from digital body composition monitor scale Tanita, aiming also to inform students about their health condition and inviting them to learn more about their health and the benefits of a healthy lifestyle.

\section{Materials and methods}

84 full time students (aged 20.9 \pm 1.21 , body mass index $22.3 \pm 0.38,8$ men and 76 women) and 19 part time students $(27.7 \pm 7.2$, body mass index $22.2 \pm 4.4$, only women) of Liepaja University and Riga Stradins University Branch of Liepaja were involved in our research. The functional state of students' organism was defined employing cardiac rhythm screening method. "Dinamika Medicine", the digital analyser of biorhythms, is a hardware-software complex, intended to analyse the human heart and brain rhythms extracted from electrocardio signal in the broadband frequency. The system is based on a new information analysis technology of non-linear signals of a different physical nature called "Fractal Neurodynamics". (Compliance Certificate of the Russian Federation, Nr. POCC RU.ME01.BO5487). The method is based on applying and analysing five heart rhythm stages and as the result of neurodynamic analysis two code combinations are developed, which consists of successive registered heart impulses with equal parameters (Ярилов С.В., 2001). Such methodical algorithm obtained in a particular period of time gives information about the functional state of the human organism based on the basic levels of heart rhythm regulation. For this research we chose the general functional diagnostic parameters of organism, which are automatically analysed by "Dinamika Medicine" system showing quantitative criteria (percentage) that define the following human health qualities: 1) parameter (A) indicates the adaptation level of cardiovascular system; 2) parameter (B) indicates the regulation of autonomous vegetative system; 3) parameter (C) indicates the central and neiro-hormonal heart rhythm regulation; 4) parameter (D) shows psycho-emotional condition; 5) parameter $(\mathrm{H})$ shows the general integral health condition (Баевский, Р. М.). The given parameters of "Dinamika Medicine" are from $60 \%-100 \%$.

The students' body composition was assessed using the body composition monitor Tanita (Model: BC-545). The following parameters were chosen: weight, muscle mass percentage in relation to the body mass, body water percentage in relation to the body mass, bone mass, body fat percentage in relation to body mass, muscle mass and type of body structure (physical 
development rating), visceral (internal fat ratio), kcal needed for basic metabolism (BMR indicates the number of calories required for a basal metabolism), metabolic age un BMI (body mass index). For assessing the body mass index the classification of World Health Organization approved in 1995 was employed. It has four stages: BMI $<18.5$ - insufficient body mass, 18.524.9 - normal body mass, 25-29.9 - increased weight, over 30 - obesity. From all these indicators we will present the most important ones: BMI; muscle mass and body structure (physical development) types: type 1 - small frame overfat (a person seems to have a healthy body type based on physical appearance, however, he/she has a high body fat percentage with a low muscle mass); level 2 - medium frame overfat (high body fat percentage with moderate muscle mass level); type 3 - large frame overfat (both high body fat percentage and a high muscle mass); type 4 - not trained (an average body fat percentage and less than average muscle mass level); type 5 - normal (an average level of both body fat and muscle mass); type 6 - normal/ muscular (an average body fat percentage and a higher than normal muscle mass level); type 7 - thin (both lower than normal body fat percentage and muscle mass level); type 8 - thin and muscular (athlete) (lower than normal body fat percentage while having adequate muscle mass); type 9 - very muscular (athlete) (lower than normal body fat percentage while having above average muscle mass); relation of bone mass to the body mass (under $50 \mathrm{~kg}-1.95 \mathrm{~kg}$; from $50-70 \mathrm{~kg}-2.4 \mathrm{~kg}$, over 70 $\mathrm{kg}-2.95 \mathrm{~kg}$ ); percentage of water in the organism (norm $45 \%-60 \%$ for women, $50 \%-65 \%$ for men).

Students' self-assessment is performed using the survey method based on American College of Health Association and the National College Health Risk Behaviour Survey (NCHRBS) adjusting it to the goals of our research in order to define the health assessment of students and health-related risk factors (15 questions). In this research three questions are analysed:

1) description of students' health condition (7 possible responses are organised according to the principles of Likert Scale: very poor, almost bad, rather bad than good, not bad and not good, almost good, mostly good, very good);

2) students' satisfaction with health condition - (very dissatisfied; almost dissatisfied, more dissatisfied than satisfied, almost satisfied, mostly satisfied, very satisfied);

3) how often have one seen the doctor during the last year (0 times, 1-2 times, 2-3 times, 3-5 times, 6-9 times, 10-19 times and 20 times and more). 


\section{Results}

Students' heart rate was determined in rest position (while sitting) by attaching special terminals on their forearms which fixate the heart rate, and within 3-5 minutes 300 cardio-complexes were registered. The normal functional state of the organism was found for $65 \%$ full time students, $33.2 \%$ have inappreciable diversions of a functional state from a normal state (body functional state parameters are lower than $60 \%$ ) and for $1.3 \%$ functional state parameters are lower than $30 \%$, which indicates the pre-illness state (too big tonus of regulation systems, low adaptation level, exhaustion of regulation systems). From part time students $15.8 \%$ of students showed normal functional state, inappreciable diversions of a functional state from a normal state $-68.4 \%$ of students and for $15.8 \%$ of students the functional state parameters were lower than $30 \%$. (see Fig. 1 )

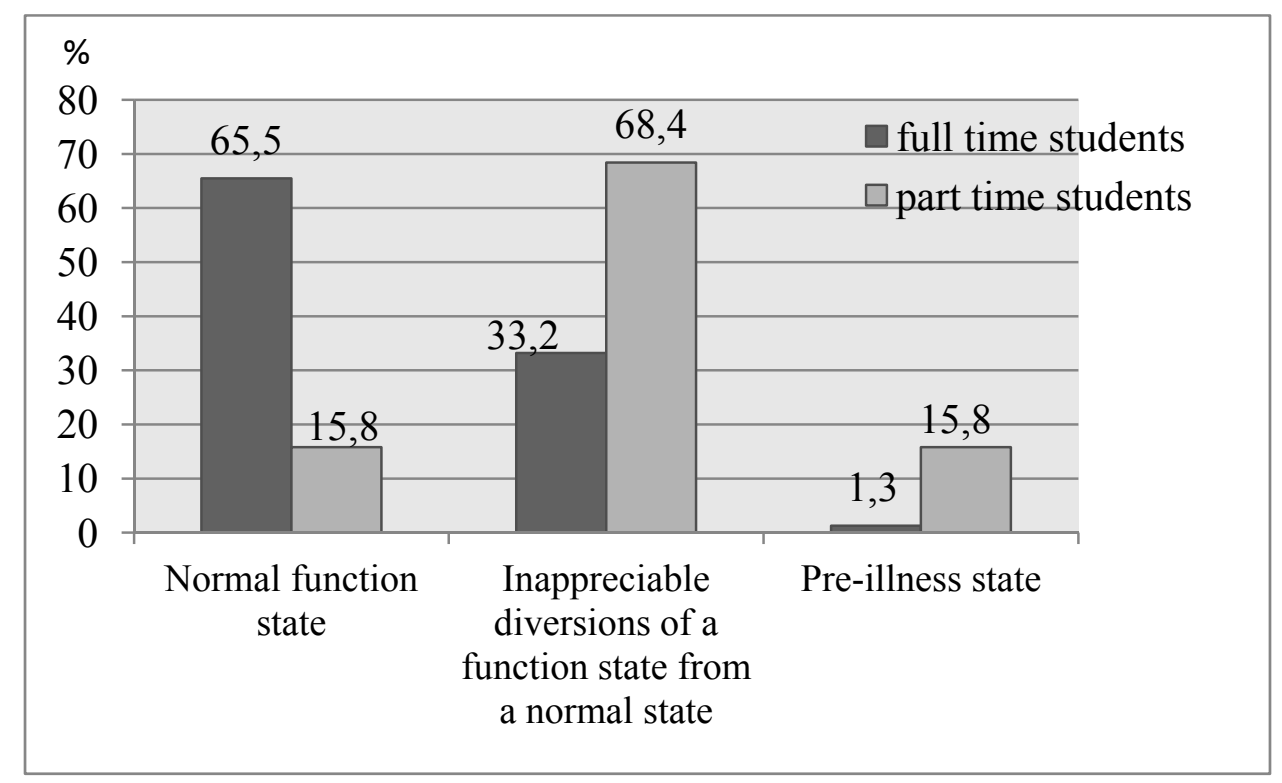

Fig. 1 Comparison of functional state of students' organism ("Dinamika Medicine") 1.attēls Studentu organisma funkcionāala stāvokḷa rādītäji("Dinamika Medicine")

Evaluating the obtained results we observed that $9.5 \%$ full time students have BMI lower than the norm ( $>18.5$ ), 75.1\% has normal BMI index, $14.2 \%$ are overweight $(<25.0)$, but $1.2 \%$ of students can be classified as obese $(<30.0)$. For part time students the following results are observed: $21.1 \%$ of students are underweight, $63.1 \%$ has a normal BMI, $10.6 \%$ are overweight, but obese -5.2 $\%$ of students (See Fig.2). 


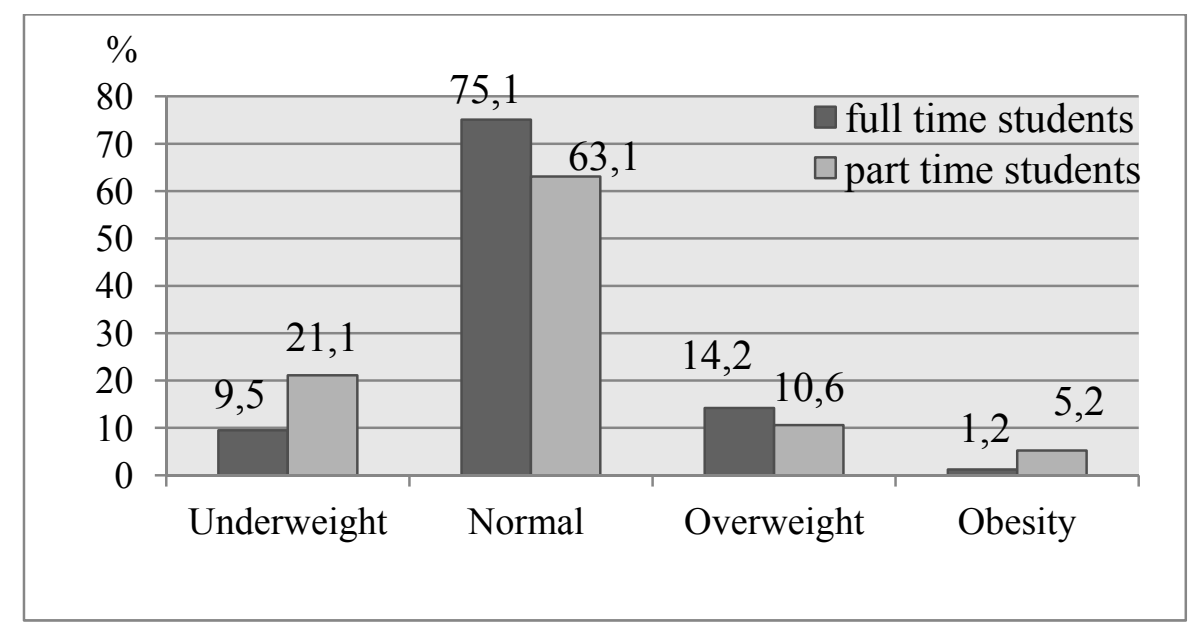

Fig. 2 BMI for full and part time students

2.attēls Studentu ĶMI rādītäji

Normal body type (type 5) is characteristic for $54.8 \%$ full time and $57.9 \%$ part time students, $8.3 \%$ full time and $5.3 \%$ part time students are in the risk group - medium frame overfat (type 2), small frame overfat (type 1) is observed for $1,2 \%$ full time students, $10,7 \%$ full time and $10.5 \%$ part time students have not trained body structure (type 4), but thin and muscular body structure (type 8 ) is observed for $13.1 \%$ full time and $15,8 \%$ part time students (see Fig.3).

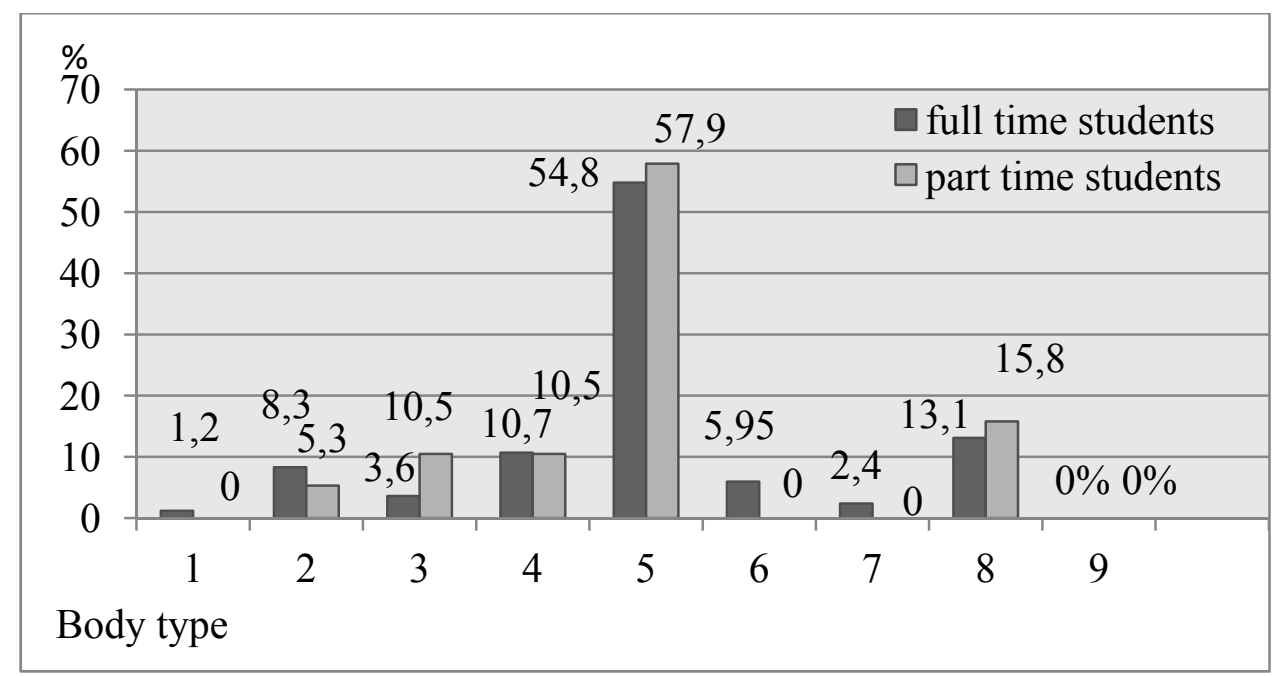

Fig. 3 Body structure types of students (1 - small frame overfat, 2 - medium frame overfat, 3 - large frame overfat; 4 - not trained; 5 -normal; 6 -normal/ muscular; 7 - thin; 8 -thin and muscular; 9 - very muscular)

3.attēls Ķ Kermeña tipu novērtējums (1 - neliela (slēpa)aptaukošanās, 2- vidēja aptaukošanās, 3 - aptaukošanās, 4 - netrenēts, 5 -normāls, 6 - normāls/muskuļots, 7 tievs, 8 - tievs un muskulsots, 9 - izteikti muskulsots)

The indicators of bone mass in relation to the body mass and percentage of water in the organism correspond to the norm both for full time and part time students, and significant differences are not observed. 
Analysing the obtained survey data we observed that $22.6 \%$ full time students evaluate their health as almost good, $53.6 \%$ as mostly good, $7.1 \%$ as very good, but $21,1 \%$ part time students evaluate their health as not good and not bad, $26.3 \%$ as almost good, $47.4 \%$ as mostly good, and $5.3 \%$ of students say their health is very good (see Fig.4).

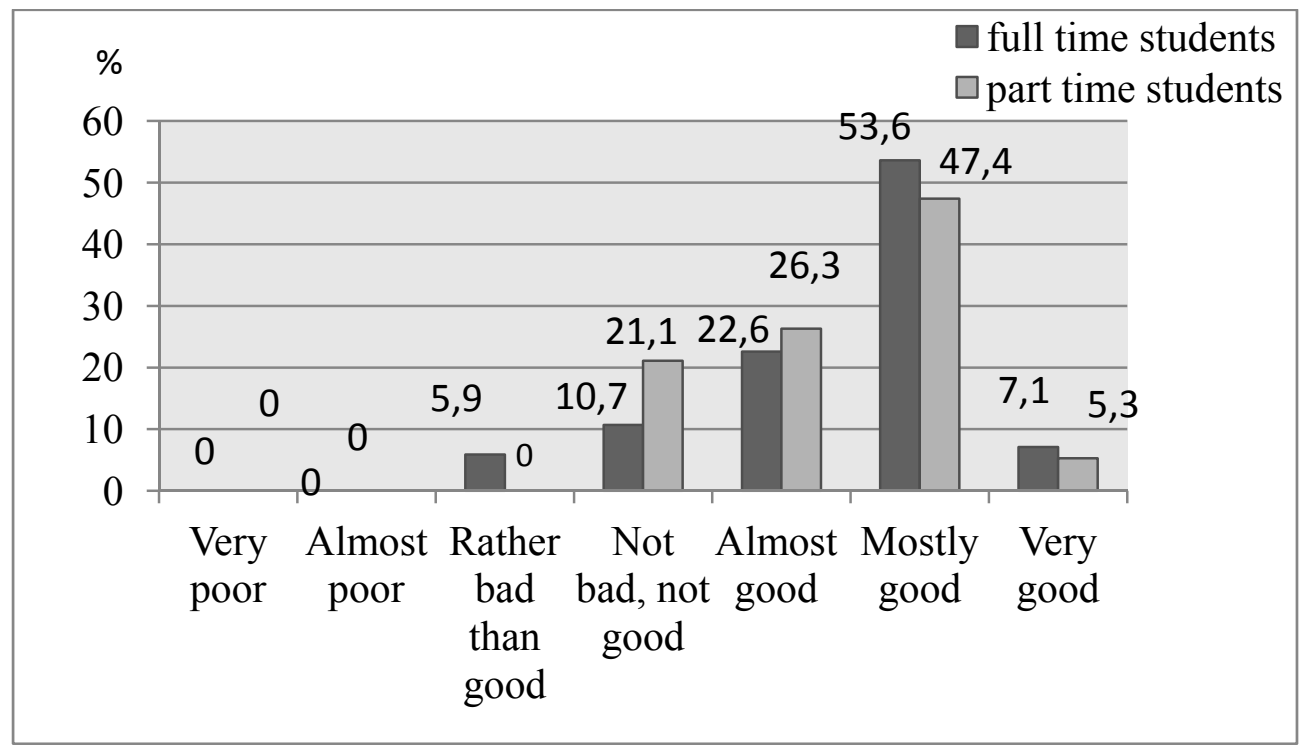

Fig. 4 Students' health self-assessment 4.attēls. Studentu veselības pašnovērtējums

Summarizing survey data about students' satisfaction with their health condition, it was observed that $52.2 \%$ full time students are fully satisfied and very satisfied with their health condition, $26.1 \%$ are almost satisfied, $42 \%$ part time students are fully satisfied and very satisfied with their health condition, $31,6 \%$ are almost satisfied with their health condition. $15.6 \%$ full time and 29.6 $\%$ part time students have not seen any doctors during the past year, $46,4 \%$ full time and $42.6 \%$ part time students have seen the doctor once or twice a year, 19 $\%$ full time and $31.6 \%$ part time students -2 or 3 times a year, $11.9 \%$ full time and $15.8 \%$ part time students $-3-5$ times a year, $5.9 \%$ full time and $5.3 \%$ part time students - 6-9 times a year, but $1.2 \%$ full time and $5.3 \%$ part time students have seen the doctor more than 10 times a year.

The obtained data - the general functional state of students' organism, body composition and health condition self-assessment we analysed using nonparametric data processing method (Spearman`s rho Sig. (1-tailed). Data was processed using SPSS 16.0 programme. The following correlations were found:

1. Relationship between self-assessment of health condition and general parameters of functional status of students' organism. 1.1. Negative weak relationship between self-assessment of health condition and general parameters of functional status of students' organism (HR) $r_{s}=-0.240 ; p<$ 0,01 , the lower is HR (heart frequency), the better is the health self- 
assessment; 1.2. Positive weak relationship between a self-assessment of health condition and general parameters of functional status of students' $\operatorname{organism}(\mathrm{A}) \mathrm{r}_{\mathrm{s}}=0.249 ; \mathrm{p}<0.01 ;(\mathrm{B}) \mathrm{r}_{\mathrm{s}}=0.207 ; \mathrm{p}<0 . .05 ;$ (D) $\mathrm{r}_{\mathrm{s}}=0.182$; $\mathrm{p}<0,05(\mathrm{H}) \mathrm{r}_{\mathrm{s}}=0.223 ; \mathrm{p}<0.05$, the higher the student body's general functional parameters, the higher the self-evaluation of health.

2. Relationship between the body composition types and health self-assessment.

2.1. Insignificant positive mutual relationship is between the body composition types (less obese, the better the health status) $r_{s}=0.193 ; p$ $<0.05$ and health self-assessment.

2.2. Insignificant mutual negative correlation is between the satisfaction with their health status and BMI $r_{s}=-0.188 ; p<0.05$ and weak correlation with percentage of the fat $\mathrm{r}_{\mathrm{s}}=0.239 ; \mathrm{p}<0.01$, if the BMI and fat percentage is less, the satisfaction with one's health condition is bigger. 2.3. Mutual positive weak correlation is between the satisfaction with the health condition and relations of $\mathrm{H} 2 \mathrm{O}$ in one's body $\mathrm{r}_{\mathrm{s}}=0.226, \mathrm{p}$ $<0.01$, if percentage of $\mathrm{H} 2 \mathrm{O}$ is sufficient, the stronger is the satisfaction with their health condition. Mutual weak negative correlation between students' satisfaction with their health and metabolic age $r_{s}=0.226 ; p<$ $0,01, r_{s}=-0.209 ; p<0,01$ and insignificant correlation with amount of inner fat $r_{s}=-0.179 ; p<0.05$, if these indicators are smaller, the more satisfied one is with his/her health. Insignificant correlation is between the frequency of physician visits and students' $\mathrm{r}_{\mathrm{s}}=0.164 ; \mathrm{p}<0.05$ and weak with BMI rs $=254 ; \mathrm{p}<0.01$, if the weight and BMI are bigger, students look to see the doctor more often.

3. Relationship between general functional state of the organism and the body composition.

3.1. Insignificant negative relationship is between the indicator of the general functional state of the organism HR with BMI $r_{s}=-0.169 ; p<0.05$, if the heart rate increased, the BMI is lower .

3.2. Insignificant negative correlation is between the index (B) and the metabolic age $r_{s}=-0.169 ; p<0.05$, if (B) parameter is higher pointing at regulation of autonomous regulation system, the metabolism age is lower.

4. Relationship between overall functional status parameters. 4.1. An average strong negative correlation is found between $\mathrm{HR}$ and students body functional state (A) - $\mathrm{r}_{\mathrm{s}}=-0.451 ; \mathrm{p}<0.01 ;(\mathrm{B})-\mathrm{r}_{\mathrm{s}}=-0.643 ; \mathrm{p}<0.01 ; \mathrm{p}<$ 0,$01 ;(\mathrm{H})-\mathrm{r}_{\mathrm{s}}=-0.469 ; \mathrm{p}<0.01$ and weak between $(\mathrm{C})-\mathrm{r}_{\mathrm{s}}=-0.232 ; \mathrm{p}<$ 0.01 and (D) $-r_{s}=-0.286$ parameters, the lower the heart frequency, the better are the indicators of functional state of students' organisms. 4.2. Between the indicators of general functional state of students' organism $(A),(B),(C),(D),(H)$ there is a strong mutual correlation $\left(r_{s}=0.675-0.944\right.$ $\pm 0.269 ; \mathrm{p}<0.01)$. 
5. Relationship between health self-assessment, satisfaction with their health and frequency of visits to the doctor. High positive correlation is between students' health self-assessment (the higher the self- assessment is, the greater is satisfaction with the health) and satisfaction with one's health $r_{s}=0.769 ; p$ $<0.01$. Negative weak correlation is between the satisfaction with one's health condition $r s=-0.199, p<0.05$ and frequency of the visits to the doctor.

6. There is a negative weak correlation between the parameters of students' age and their functional condition (A) $r_{s}=-0.228, p<0.05$; (B) $r_{s}=-0.261, p<$ $0.01 ;$ (C) $\mathrm{r}_{\mathrm{s}}=-0.263, \mathrm{p}<0.01$; (D) $\mathrm{r}_{\mathrm{s}}=-0.259, \mathrm{p}<0.01$; (H) $\mathrm{r}_{\mathrm{s}}=-0.284, \mathrm{p}<$ 0.01 ; negative weak correlation between students' age and basic metabolic rates $r_{s}=-0.243, p<0.01$ and students' age and frequency of the doctor's visits $r_{s}=-0.296, p<0.01$.

\section{Discussion}

The obtained research data about the general functional state of students' organism clearly show that with the increase of students' age the general functional state of organism is gradually deteriorating, and it can be influenced by several factors, for example, insufficient physical activity, stress, genetics, etc. (Батоцыренова Т.Е., Иванов С.В., 2011; Баевский, M.P., et. al. 2009; Dr. Davy K.P. et.al., 1998). In the literature we find analysis of correlations between the functional status of organism and physical activity, body's functional status and physical fitness, body composition and dietary habits, as well as BMI and physical activity. In our research, for determining the functional status of students' organism we employed the general health indicators according to the classification of cardiovascular regulation mechanism elaborated by R.M. Bajevskij (Баевский, Р. М., ПАРС - показатели активности регуляторных систем). Body composition measurements were made using electronic scales Tanita. The students involved in this research were divided in two groups representing the full and part time students. Therefore, an objective comparison with other research studies cannot be made; we can compare our research only with other related studies, where respondents are selected by other features, such as normal body weight, increased body weight, or regulation of vegetative system. Therefore, it can be concluded that there is a weak correlation between the body composition and heart rate variability (HRV). Карпенко Ю. Д., Димитриев Д. А., 2012; Лопатина Л.A. et al, 2011; Mouridsen Mette Rauhe et. al., 2012).

Despite the fact that the increased or diminished parameters of BMI and body composition are the risk factors for different diseases, in this research the correlations between the functional status of organism, BMI, and body composition measurements are relatively weak, which shows that with the negative body composition measurement results the organism's functional state 
results can be positive and vice versa. Partly this situation can be explained by the age limit of the respondents $(19-27)$, as people in this age are still in relatively good health and their functional status of the organism has not yet exhausted its reserves.

The indicators of BMI in our research match the data from Latvia Centre of Health Economics (2011), which shows $11.3 \%$ overweight and obesity cases in the age group from 15 to 24 years. Also the research results on health selfassessment is similar to the research conducted by Latvia Centre of Health Economics (2011), where in the age group from 14-24 years $51.4 \%$ of respondents evaluate their health as good, $30.7 \%$ as rather good, but in the age group from 25-34 years the health self-evaluation becomes more critical: $37 \%$ respondents evaluate their health as good and $32 \%$ as rather good.

\section{Conclusions}

1. "Dinamica Medicine" measurements show a rapid decline in functional state of the organism (for $33.3 \%$ ) with the increase of the age.

2. The indicators of BMI in our research match the data from Latvia Centre of Health Economics (2011), which shows $11.3 \%$ overweight and obesity cases in the age group from 15 to 24 years.

3. The health self-assessment for full and part time students is rather high: 60.7 $\%$ full time students evaluate their health as mostly good and very good and $22.6 \%$ as almost good; $52.7 \%$ part time students evaluate their health as mostly good and very good and $26.3 \%$ as almost good. $10.7 \%$ full time and $21.1 \%$ part time students say their health is average (not good and not bad).

4. The students' functional status of organism, body composition and health self- assessment correlation can be evaluated as weak. A significant correlation between the students' functional status and body composition is not found.

\section{Kopsavilkums}

Pētījuma mērḳis ir noteikt pašreizējo Liepājas Universitātes un Rīgas Stradiṇu Universitātes Liepājas filiāles medicīnas koledžas studentu organisma funkcionālo stāvokli, ķermeña kompozīiju un veselības pašnovērtējuma mijsakarības. Pētījumā piedalījās 84 Liepājas Universitātes un Stradinu Universitātes Liepājas filiāles medicīnas koledžas pilna laika studenti un 19 nepilna laika studenti. Materiāli un metodes. Studentu organisma funkcionālais stāvoklis noteikts izmantojot sirds ritma skrīninga metodi, pielietojot apartūru "Dinamika Medicine" (Saint-Petersburg, Russia, 2007) Studentu ķermeña kompozīija tika noteikta izmantojot elektroniskos svarus „Tanita” (Model:BC-545). Veselības pašvērtējums noteikts izmantojot aptaujas metodi, dotajā pêtījumā izmantoti 3 jautājumi, lai noskaidrotu studentu veselības 
pašnovērtējumu, apmierinātību ar savu veselības stāvokli un ārsta apmeklējuma biežumu. Iegūtos datus - studentu organisma vispārējo funkcionālo stāvokli, ķermeņa kompozīciju un veselības stāvokḷa pašvērtējuma kopsakarības analizējām pielietojot neparametrisko datu apstrādes metodi Spirmena korelācija. Dati tika apstrādāti izmantojot SPSS 16.0 programmu. Secinājumi. Palielinoties studentu vecumam studentu funkcionālais stāvoklis pazeminās, savukārt k̦ermeṇa kompozīcijas rādītājos būtisku atšķirību nav, veselības pašnovērtējums nedaudz (par $6 \%$ ) augstāks pilna laika studentiem. Dotajā pētîjumā nav atrastas būtiskas mijsakarības starp studentu organisma vispārējā funkcionālā stāvokḷa mērījumiem un ķermeṇa kompozīcijas mērījuma rādītājiem.

\section{Literatūra \\ Bibliography}

1. Adams, T., \& Moore, M. (2007). High-Risk Health and Credit Behavior Among 18- to 25-Year-Old College Students. Journal of American College Health, vol.56 (2) 101 108.

2. Davy Kevin, P., Christopher, A. Desouza., Pamela, P. Jones. and Douglas, R. Seals. (1998). Elevated heart rate variability in physically active young and older adult women. Clinical Science. 94, 579-584 [20.02.2013] From: http://www.ncbi.nlm.nih.gov/pubmed/9854454

3. Mette Rauhe Mouridsen, Nathalie Tommerup Bendsen, Arne Astrup, Steen Bendix Haugaard, Zeynep Binici and Ahmad Sajadieh. (2012). Modest weight loss in moderately overweight postmenopausal women improves heart rate variability. European Journal of Preventive Cardiology published online 28 March 2012 DOI: $10.1177 / 2047487312444367$

4. Kaupužs, A., Lārin̦š, V.(2010). Rēzeknes augstskolas pirmā kursa studentu fiziskā aktivitāte. Sporta izglìtības aktualitātes, zinātnisko rakstu krājums, Liepājas universitāte, Liepāja, 38. - 44.lpp.

5. Latvia Center of Health Economics. (2011). Latvijas Veselības ekonomikas centrs. Latvijas iedzīvotāju veselību ietekmējošo paradumu pētījums, 2010. ISBN 978-9984-837$35-2$ (pdf)

6. Youth Risk Behavior Surveillance: National College Health Risk Behavior Survey -United States (1995). [22.08.2012.]From:

http://www.cdc.gov/mmwr/preview/mmwrhtml/00049859.htm

7. System of complex computer-aided inspection of the functional condition of human organism. Dinamika medicine. Документация пользователя. Saint-Petersburg, Russia.(2007). From: http://www.mdevice.eu/files/dinamika/usermanualrus.pdf

8. Баевский, Р. М. Оценка уровня здоровья и риска развития заболеваний с помощью uифрового анализатора биоритмов «Омега-М» . [22.02.2013.] From: http://dinamikatech.dyn.ru/media/upload/article/Assessment_of_the_level_of_health_thro ugh the_Omega.Medicine.pdf

9. Баевский, Р. М., Иванов, Г.Г., \& Рыбыкина, Г.В. (1999). Современное состояние исследований по вариабельности сердечного ритма [Current status of research on heart rate variability]. Россия, Вестник Аритмологии, №14, c.71 - 75. From://www.vestar.ru/article.jsp?id=2311

10. Батоцыренова, Т.Е., Иванов, С.В.(2011). Организация системы мониторинга по физическому здоровью студентов.[System of monitoring the physical health of 
students.] Материаль докладов всероссийской научно-практической конференции «O повышении роли физической культуры и спорта в развитии личности студентов» (17-18 ноября 2011года) / Отв.ред.: М.Я. Виленский, С.И.Филимонова. - М.:, 2011. - 316 с

11. Карпенко, Ю. Д. , Димитриев, Д. А.(2012).Влияние индекса массы тела на вариабельность сердечного ритма у студентов в условиях относительного покоя и экзаменационного стресса. [The influence of body mass index on heart rate variability in students in terms of relative rest and exam stress.]Медицина и образование в Сибири. № $6 \quad-2012 \quad$ г. 6 УДК 612.172.2-057.875:616-003.96. From: http://www.ngmu.ru/cozo/mos/article/text_full.php?id=848

12. Лопатина, Л.А., Семенов, С.Н., Сереженко, Н.П., Зеленина, М.Т.(2011).Вариабельность сердечного ритма у юношей с разным компонентным составом тела. [Heart rate variability in boys with different component composition of the body.] Вариабельность сердечного ритма: Теоретические аспекты $u$ практическое применение: материаль V всеросс. симп. / отв. ред. Р.М. Баевский, Н.И. Шльк, Ижевск: Изд-во «Удмуртский университет», 2011, 597 с. $(96$ - 103 с) УДК $612.821 .8(063)+616.1(063)$

13. Чуян, Е.Н., Бирюкова, Е.А., \& Раваева, М.Ю. (2008). Комплексный подход к оценке функционального состояния организма студентов [An integrated approach to assessing the functional state of the students]. Учёные записки Тавричевского национального университета им.В.И.Вернадского. Серия Биология, химия Том 21 (60), № 1.c.123 - 139, УДК 612.014

14. Ярилов, С.В.(2001). Физиологические аспекты новой информационной технологии анализа биофизических сигналов и принципы технической реализащии [Physiological aspects of the new information technology biophysical signal analysis and principles of technical realizations].Санкт-Петербург.[20.02.2012.]

From:

http://dinamikatech.dyn.ru/dinamika_technologies/technology/for_read/article_list/

\begin{tabular}{|r|l|}
\hline Helēna & Liepaja University \\
Vecenāne & Liela Street 14, Liepaja, Latvija,LV-3600 \\
& E-mail: helena.vecenane@liepu.lv \\
\hline Andra & Latvian Academy of Sport Education \\
Fernāte & Brivibas Gatve 333, Riga, Latvia, LV-1006 \\
& E-mail:andra.fernate@,1spa.lv \\
\hline
\end{tabular}

